\title{
Photochemical and microbial degradation of external dissolved organic matter inputs to rivers
}

\author{
Tracy N. Wiegner*, Sybil P. Seitzinger \\ Institute of Marine and Coastal Sciences, Rutgers, The State University of New Jersey, 71 Dudley Road, New Brunswick, \\ New Jersey 08901-8521, USA
}

\begin{abstract}
Photochemical and microbial degradation of external inputs of dissolved organic matter (DOM) from both natural (forests) and anthropogenic (swine and equine pastures) non-point sources to rivers were examined through field and laboratory microcosm experiments. Little or no photochemical degradation of DOM to inorganic $\mathrm{N}$ or $\mathrm{P}$ occurred in either the agricultural or forest runoff. The dissolved organic carbon (DOC), dissolved organic nitrogen (DON), $\mathrm{NH}_{4}{ }^{+}$, and $\mathrm{PO}_{4}{ }^{3-}$ concentrations did not change during the photochemical experiments for any of the sources examined. A small, but significant increase in the $\mathrm{NO}_{3}{ }^{-} / \mathrm{NO}_{2}{ }^{-}\left(+0.7 \mu \mathrm{M}_{i} \mathrm{p}=0.004\right)$ concentration was detected in the forest runoff, suggesting that a small fraction (4 to $9 \%$ ) of the DON may be photochemically degraded to dissolved inorganic nitrogen (DIN). Bacteria readily utilized DOC and DON in the agriculture and forest runoff. The percent of DOC and DON consumed by the bacteria ranged from 6 to $14 \%$ and 21 to $25 \%$, respectively. Light exposure did not alter the biological availability of the DOC and DON in either the equine pasture or forest runoff. Our results emphasize the importance of microbial processes in degrading DOM in riverine environments; they appear to degrade DOM more rapidly than photochemical processes and may be more important in affecting the quantity and quality of the DOM exported from rivers to estuaries.
\end{abstract}

KEY WORDS: Bacteria · Dissolved organic carbon · Dissolved organic nitrogen · Non-point sources · Photochemical processes · Rivers

Resale or republication not permitted without written consent of the publisher

\section{INTRODUCTION}

Photochemical and microbial processes are important pathways for altering and removing dissolved organic matter (DOM) in aquatic systems. These processes act in conjunction with each other to affect the amount and rate at which DOM, both the carbon (DOC) and nitrogen (DON) components, are incorporated into the microbial food web (Wetzel et al. 1995, Bushaw et al. 1996, Miller \& Moran 1997, Jørgensen et al. 1998, Bushaw-Newton \& Moran 1999). Photochemical processes can alter the DOM pool by releasing inorganic compounds such as ammonia $\left(\mathrm{NH}_{4}{ }^{+}\right)$, nitrite $\left(\mathrm{NO}_{2}^{-}\right)$, phosphate $\left(\mathrm{PO}_{4}{ }^{3-}\right)$, dissolved inorganic carbon (DIC: sum of dissolved $\mathrm{CO}_{2}, \mathrm{H}_{2} \mathrm{CO}_{3}, \mathrm{HCO}_{3}{ }^{-}$, and $\mathrm{CO}_{3}{ }^{2-}$ ), and carbon monoxide (CO) (Francko \& Heath 1982,

*E-mail: wiegner@imcs.rutgers.edu
Miller \& Zepp 1995, Bushaw et al. 1996, Granéli et al. 1996, Gardner et al. 1998, Kieber et al. 1999). Sunlight can also cleave large DOM molecules into smaller and potentially more labile entities (Mopper \& Stahovec 1986, Kieber \& Mopper 1987, Kieber et al. 1989, Wetzel et al. 1995, Jørgensen et al. 1998). As a result of these processes, the DOM and its photo-products can then be taken up by bacteria and phytoplankton and incorporated into the biological cycle. Bacteria and phytoplankton can directly take up DOM through the secretion of exoenzymes and cell surface oxidation (e.g. Palenik \& Morel 1990, Anita et al. 1991, Pantoja \& Lee 1994). Microorganisms can also remineralize the DOM, releasing $\mathrm{NH}_{4}{ }^{+}, \mathrm{PO}_{4}{ }^{3-}$, and $\mathrm{CO}_{2}$ back into the surrounding environment (Goldman et al. 1987).

Riverine DOM inputs were historically considered recalcitrant because of their high $\mathrm{C}: \mathrm{N}$ ratio $(\sim 50)$, the reported conservative mixing in some estuaries, and 
the predominance of high molecular weight (HMW) compounds (Mantoura \& Woodward 1983, Amon \& Benner 1996a). Recent studies have begun to demonstrate that not all of the HMW DOM pool is refractory. On average, about $17 \%$ of the carbon component in DOM from lakes, rivers, and marine environments has been found to be biologically available (Søndergaard \& Middelboe 1995). Bioassays and non-conservative mixing curves in river plumes have demonstrated that the nitrogen component in DOM is also labile (Carlsson et al. 1993, 1999, López-Veneroni \& Cifuentes 1994, Peierls \& Paerl 1997, Seitzinger \& Sanders 1997, 1999, Stepanauskas et al. 1999). In the Delaware and Hudson rivers, from 40 to $72 \%$ of the DON was found to be biologically available to estuarine microbes (Seitzinger \& Sanders 1997).

The relative importance of photochemical and microbial degradation of DOM in the aquatic environment is not yet well understood. Numerous studies have examined either photochemical or microbial degradation of DOM; however, few have directly compared the 2 pathways. These studies have focused primarily on the degradation of DOC $;$ researchers have only begun to examine DON. The goal of this study was to examine photochemical and microbial degradation of DOC and DON from anthropogenic and natural non-point sources. Non-point source runoff was chosen as a DOM source because it may be an important external input of DOM and pollution to rivers (Sharpley et al. 1988, Heathwaite 1993). Photochemical and microbial degradation of DOC and DON were examined through both field and laboratory microcosm experiments. Photochemical degradation experiments investigated the ability of different regions of the electromagnetic spectrum to degrade DOC and DON into inorganic components. Microbial experiments further examined how photochemical processes affect DOM biological availability to the bacteria community.

\section{MATERIALS AND METHODS}

Sample collection. Agriculture and forest sites located in New Jersey were selected for non-point source runoff collection. These sites included swine and equine pastures located on Cook College, Rutgers University, New Brunswick (40²8' 65" N, 74²6' 20" W) and a mixed hardwood forest located on Round Mountain, Stanton (40 34' 25" N, 74 50' 17" W). Agriculture runoff was collected down-slope of the animal pastures in a subsurface water collector (Seitzinger et al. unpubl. data) consisting of a PVC pipe with drainage holes wrapped in a GeoSieve (Drainage Products ${ }^{\mathrm{TM}}$, Inc. Windsor Locks, CT) sleeve. The collectors were buried 18 to $23 \mathrm{~cm}$ below the soil surface and above a layer of red/orange clay. The animal density in the pastures ranged from 2 to $3 \mathrm{ha}^{-1}$. Forest runoff was sampled from a first-order stream, approximately $30 \mathrm{~cm}$ wide, running through a mixed hardwood forest dominated by black oak Quercus velutina, white oak Quercus alba, American beech Fagus grandifolia, yellow poplar Liriodendron tulipfera, red maple Acer rubrum, and bitternut hickory Carya cordiformis.

Runoff was collected from each site during or immediately following a rainstorm event in June or August of 1997. Water was collected during times of increased riverine discharge when soluble organic matter concentrations are known to be high (Richey et al. 1985, Lewis \& Saunders 1989). The water was collected in an acid-washed 201 polyethylene cubitainer and transported on ice to the laboratory. Here, it was sequentially filtered through 1.0 and $0.5 \mu \mathrm{m}$ string-wound polypropylene canister filters into an acid-washed 201 cubitainer and immediately frozen at $-20^{\circ} \mathrm{C}$. The canister filters were flushed with 201 of deionized water (DIW) before filtering the runoff. Before the photochemical experiment, the runoff was sterile filtered through a $10^{6}$ dalton polysulphone filter (tangential flow ultrafiltration; Filtron Technologies, Northborough, MA) on ice into acid-washed and autoclaved 101 polypropylene containers, and immediately frozen at $-20^{\circ} \mathrm{C}$. During this filtering process, water from a single source was collected in 3 separate containers. In order to maintain sterile conditions, water from the 3 containers was not mixed after filtering was complete. Thus, each container and subsequently replicate treatment flasks had a different starting DOC and DON concentration. Sample exposure to light was minimized during all processing steps.

Photochemical degradation experiments. Photochemical degradation experiments were performed at Laca-

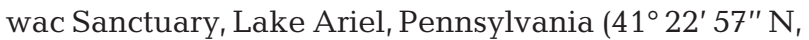
75 17' 35" W), during August, September, and October 1997. Sterile filtered runoff (swine, equine, and forest) and control water (autoclaved DIW) were allocated into sterile and pre-combusted $1.5 \mathrm{l}$ quartz (light treatments) and $2 \mathrm{l}$ borosilicate boiling (dark controls) flasks. Duplicate flasks were irradiated under natural sunlight in incubators constructed out of black Plexiglas with tops built from either UF-5 ( $Q$ = downwelling irradiance; $Q_{\mathrm{PAR}}, 400$ to $\left.700 \mathrm{~nm}\right)$, UVT and Mylar D, $\left(Q_{\mathrm{PAR}+\mathrm{UVA}}, 320\right.$ to $\left.700 \mathrm{~nm}\right)$, and UVT ( $Q_{\mathrm{PAR}, \mathrm{UVA}+\mathrm{UVB}}, 280$ to $700 \mathrm{~nm}$ ), and black Plexiglas (no light: control). Light transmission cutoffs for the Plexiglas tops were $412 \mathrm{~nm}$ for UF-5, $317 \mathrm{~nm}$ for UVT and Mylar D, and below $280 \mathrm{~nm}$ for UVT. The thickness of the UF-5 and UVT Plexiglas was $3.2 \mathrm{~mm}$ and that of Mylar D was $0.05 \mathrm{~mm}$. Water in the flasks was continuously mixed with sterile Teflon-coated stir bars during the course of the experiment. Fluctuations in water temperature 
were minimized during the experiment by circulating water through the incubators and adding ice. Average water temperatures for the August, September, and October experiments were $\left(20 \pm 5^{\circ} \mathrm{C}\right),\left(20 \pm 3^{\circ} \mathrm{C}\right)$, and $\left(19 \pm 2{ }^{\circ} \mathrm{C}\right)$, respectively.

Initial and time-series nutrient samples for $\mathrm{NH}_{4}{ }^{+}$, $\mathrm{NO}_{3}{ }^{-} / \mathrm{NO}_{2}{ }^{-}, \mathrm{PO}_{4}{ }^{3-}$, total dissolved nitrogen (TDN), and DOC were taken over the course of 3 to $4 \mathrm{~d}$. The swine pasture, equine pasture, and forest runoff were exposed to approximately $35,21.5$, and $38 \mathrm{~h}$ of sunlight, respectively. Sterile sampling procedures were used throughout the experiments. $\mathrm{NH}_{4}{ }^{+}$was measured using both standard autoanalyzer and manual methods (Lachat, Inc. QuickChem 31-107-06-1-A, Milwaukee, WI; Solórzano 1969). Both $\mathrm{NO}_{3}{ }^{-} / \mathrm{NO}_{2}{ }^{-}$(Lachat QuickChem Method 31-107-04-1-A) and $\mathrm{PO}_{4}{ }^{3-}$ (Lachat QuickChem Method 31-115-01-3-A) were measured using standard autoanalyzer methods. TDN was analyzed by hightemperature combustion followed by chemiluminescent detection of nitric oxide using an Antek Model 7000 Total N Analyzer (Antek, Inc., Houston, TX) equipped with a quartz combustion tube $\left(1000 \pm 10^{\circ} \mathrm{C}\right)$ and a ceramic insert (Seitzinger \& Sanders 1997). TDN samples were preserved in capped autosampler vials with $3 \mathrm{~N} \mathrm{HCl}(7.5 \mu \mathrm{l}$ acid per $1.5 \mathrm{ml}$ sample) and stored in the dark at $4^{\circ} \mathrm{C}$. Blanks consisted of DIW. Both inorganic $\left(\mathrm{NH}_{4}{ }^{+}\right.$and $\left.\mathrm{NO}_{3}{ }^{-} / \mathrm{NO}_{2}{ }^{-}\right)$and organic (urea) standards for TDN analysis were prepared in DIW. DON was determined by the difference between TDN and DIN. DOC was measured by high temperature combustion (Shimadzu TOC-5000A) following the recommendations of Sharp et al. (1993). All nutrient and DOC samples were immediately frozen at $-20^{\circ} \mathrm{C}$ following sampling. Immediately following each photochemical degradation experiment, water from each treatment flask was frozen at $-20^{\circ} \mathrm{C}$ in an acidwashed $500 \mathrm{ml}$ polyethylene container and stored for up to 2 mo before being used in the microbial degradation experiments.

Light measurements were made with a Biospherical Instruments Inc. (BSI) GUV-521 UV radiometer at Lacawac Sanctuary. The radiometer measured downwelling irradiance simultaneously at 4 wavebands in the UV region (380, 340,320 , and $305 \mathrm{~nm} ; 8$ to $10 \mathrm{~nm}$ bandwidths) as well as broadband PAR (400 to $700 \mathrm{~nm}$ ). Irradiance was recorded by a Campbell Scientific, Inc. CR-10 datalogger at $1 \mathrm{~s}$ intervals and averaged at 15 min intervals. Estimates of total incident UVB and UVA were obtained from the narrow band data using a model described in Morris \& Har-
Table 1. Light exposure $\left(\mathrm{J} \mathrm{m}^{-2}\right)$ in photochemical degradation experiments UF-5: $Q_{\mathrm{PAR}}, 400$ to $700 \mathrm{~nm}$; UVT + Mylar D: $Q_{\mathrm{PAR}+\mathrm{UVA}}, 320$ to $700 \mathrm{~nm}$; UVT: $Q_{\mathrm{PAR}, \mathrm{UVA}+\mathrm{UVB}}, 280$ to $700 \mathrm{~nm}$

\begin{tabular}{|c|c|c|c|}
\hline Plexiglas filter & UVB & UVA & PAR \\
\hline \multicolumn{4}{|c|}{ Swine pasture runoff (Aug 19-22, 1997) } \\
\hline $\mathrm{UF}-5$ & 48.5 & 3230 & 2630000 \\
\hline UVT+Mylar D & 33300 & 2500000 & 2630000 \\
\hline UVT & 115000 & 2590000 & 2630000 \\
\hline \multicolumn{4}{|c|}{ Equine pasture runoff (Sep 17-19, 1997) } \\
\hline UF-5 & 45.2 & 3010 & 2660000 \\
\hline UVT+Mylar D & 31100 & 2330000 & 2660000 \\
\hline UVT & 108000 & 2420000 & 2660000 \\
\hline \multicolumn{4}{|c|}{ Forest runoff (Oct $7-10,1997)$} \\
\hline UF-5 & 41.2 & 2750 & 2690000 \\
\hline UVT+Mylar D & 28400 & 2130000 & 2690000 \\
\hline UVT & 98100 & 2210000 & 2690000 \\
\hline
\end{tabular}

greaves (1997). Spectra generated from the model were integrated to estimate daily incident UVB and UVA irradiance. UVB and UVA exposure for each treatment was calculated by multiplying the daily incident irradiance $\left(\mathrm{J} \mathrm{m}^{-2} \mathrm{~nm}^{-1}\right.$ at $1 \mathrm{~nm}$ intervals $)$ from the modeled solar spectrum by the transmittance (at $1 \mathrm{~nm}$ intervals) of the Plexiglas filters. The UVB and UVA dose received by each treatment over the course of the experiment was calculated by summing the daily irradiance (280 to $320 \mathrm{~nm}$ for UVB and 321 to $400 \mathrm{~nm}$ for UVA) (Table 1).

Microbial degradation experiments. Lability of DOM before and after light exposure was quantified through a series of microbial degradation experiments (Fig. 1). The biological availability of the DOM was determined by changes in the DOC and DON concentration over the course of the experiments. Our first experiment

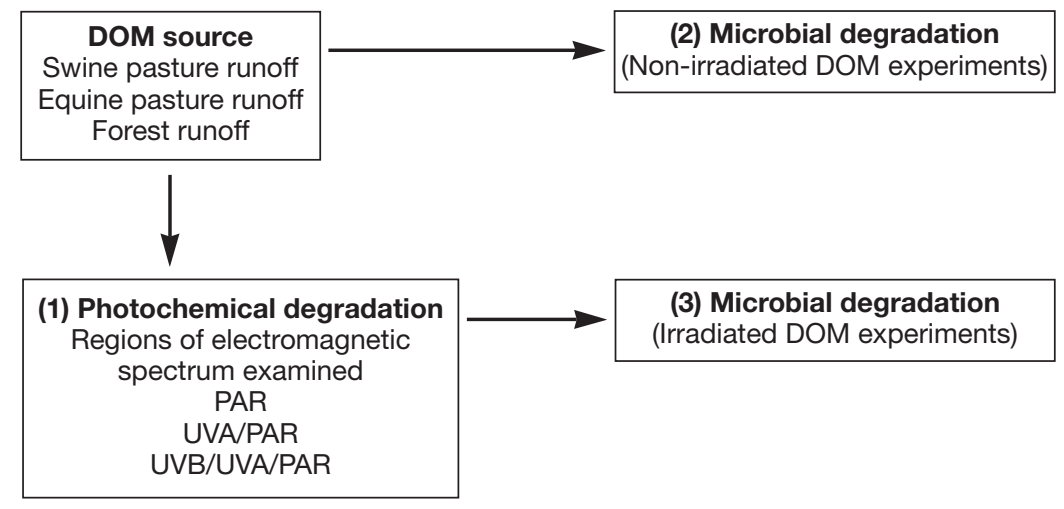

Fig. 1. Experimental design for photochemical and microbial DOM degradation experiments. (1) DOM from non-point source runoff was exposed to different regions of the electromagnetic spectrum using natural sunlight; (2) biological availability of non-irradiated DOM was examined through laboratory microcosm experiments using the same non-point source runoff; (3) further microbial experiments examined how photochemical processes affect DOM biological availability to the microbial community 
looked solely at the microbial degradation of DOM (swine and equine pasture and forest runoff; nonirradiated DOM experiment). Our second experiment examined the effect of previous light exposure on the biological availability of DOM (equine pasture and forest runoff; irradiated DOM experiment). In this second experiment, water from the replicate photochemical treatment flasks was combined prior to sterile filtration to ensure that each treatment had the same initial DOC and DON concentrations.

The experimental design for both microbial degradation experiments consisted of adding freshwater bacterial concentrate to sterile filtered runoff (swine, equine, and forest) and control water (DIW) and then monitoring nutrient concentrations and bacterial production in these waters (Seitzinger \& Sanders 1997). The runoff and control water were sterile filtered through a DIW-rinsed $0.2 \mu \mathrm{m}$ Nucleopore filter into a pre-combusted 11 Erlenmeyer flask. The water was then divided into 2 pre-combusted $500 \mathrm{ml}$ borosilicate Erlenmeyer flasks to which $5 \mathrm{ml}$ of the bacteria concentrate were added to give an initial bacterial abundance of around $10^{5}$ cells ml ${ }^{-1}$ (DAPI staining method: Porter \& Feig 1980). Water for the bacteria inoculum was collected from Round Valley Reservoir, New Jersey $\left(40^{\circ} 36^{\prime} 40^{\prime \prime} \mathrm{N}, 74^{\circ} 50^{\prime} 42^{\prime \prime} \mathrm{W}\right)$, a freshwater source with a bacterial community not endemic to the runoff. The water for the bacteria inoculum was collected and filtered through a DIW-rinsed $0.5 \mu \mathrm{m}$ string-wound polypropylene canister filter to remove large particles. The inoculum was prepared by concentrating $18 \mathrm{l}$ of the reservoir water to $200 \mathrm{ml}$ using a $10^{6}$ dalton polysulphone filter (tangential flow ultrafiltration; Filtron Technologies) and pulse-sonicating it to remove the remaining protists (Seitzinger \& Sanders 1997). The flasks were covered with aluminum foil, gently stirred with Teflon-coated stir bars, and incubated in the dark at $22^{\circ} \mathrm{C}$ for $10 \mathrm{~d}$. Nutrient samples were analyzed for $\mathrm{NH}_{4}{ }^{+}, \mathrm{NO}_{3}{ }^{-} / \mathrm{NO}_{2}{ }^{-}, \mathrm{PO}_{4}{ }^{3-}, \mathrm{DON}$, and DOC using the procedures described above. Water for nutrient analysis was filtered through pre-combusted, DIW-rinsed $\mathrm{GF} / \mathrm{F}$ filters and stored frozen at $-20^{\circ} \mathrm{C}$ until analysis. All glassware used for filtering water was acid-washed and muffled at $500^{\circ} \mathrm{C}$ prior to use.

Bacterial production was measured by ${ }^{3} \mathrm{H}$-leucine incorporation using a method modified from Smith \& Azam (1992). We added $1.7 \mathrm{ml}$ of sample water to sterile $2.0 \mathrm{ml}$-capacity screw-cap microcentrifuge tubes with o-rings followed by the addition of $5 \mu \mathrm{l}$ of L-4, $5{ }^{3} \mathrm{H}$-leucine (TRK 510, Amersham, UK; $1 \mathrm{mCi} \mathrm{ml}^{-1}$ ). The solution of sample water and isotope was mixed well and incubated in the dark at $22^{\circ} \mathrm{C}$ for $30 \mathrm{~min}$. Blanks for the procedure consisted of $90 \mu \mathrm{l}$ of $100 \%$ trichloroacetic acid (TCA), $1.7 \mathrm{ml}$ sample water, and $5 \mu \mathrm{l}$ ${ }^{3} \mathrm{H}$-leucine. Triplicate microcentrifuge tubes were run for each flask and blanks were run for each treatment. The centrifugation, vortex, and wash sequence prescribed in Smith \& Azam (1992) was followed with the addition of a final $80 \%$ ethanol wash. The microcentrifuge tubes were placed into scintillation vials and radioassayed in a liquid scintillation counter (Beckman LS 6000IC). Measured ${ }^{3} \mathrm{H}$-leucine incorporation rates were converted to estimates of bacterial biomass production using theoretical conversion factors (Kirchman 1993). The increase in bacterial biomass over the course of the experiment was estimated by plotting the bacterial biomass production rate over the course of the experiment and integrating under the curve. We normalized the integrated bacterial biomass production for each source to its initial DOC concentration in order to compare bacterial biomass production estimates between sources (Meyer et al. 1987, Hopkinson et al. 1998).

Statistical analysis. Changes in the DOC, DON, $\mathrm{NH}_{4}{ }^{+}, \mathrm{NO}_{3}{ }^{-} / \mathrm{NO}_{2}{ }^{-}$, and $\mathrm{PO}_{4}{ }^{3-}$ concentrations over the course of the photochemical degradation experiments were examined through linear regression analysis $(\alpha=$ 0.05). Differences between light regimes for the photochemical degradation experiments were examined by 1 -way analysis of variance $\left(\right.$ ANOVA; Systat ${ }^{\circledR}, 6.0$ software; $\alpha=0.10$ ). Power transformations were conducted on data sets in order to satisfy the normality requirement for the ANOVA.

Statistical analyses were performed on the data from the non-irradiated and irradiated DOM microbial experiments where possible. Out of the 110 nutrient time-series measurements made for these experiments, 3 are not included in the data set (Table 2) because of unexplainable variability. Linear regression analysis $(\alpha=0.05)$ was used to examine the effect of microbial processes on the non-irradiated DOM concentration. ANOVA (Systat ${ }^{\circledR}, 6.0$ software; $\alpha=0.05$ ) was used to examine differences in the DOM biological availability between runoff sources and photochemical light treatments. Rank-transformations were conducted on data sets in order to satisfy the equality of variance requirement for the ANOVA (Potvin \& Roff 1993). Post hoc analyses were performed using the Tukey test $(\alpha=0.05)$.

\section{RESULTS}

\section{Photochemical degradation of DOM}

DOC and DON concentrations in the agriculture and forest runoff did not significantly change $(p>0.05)$ over the course of the photochemical experiments in 45 out of the 48 time-series measurements (Fig. 2). The variability seen in both the DOC and DON concentra- 

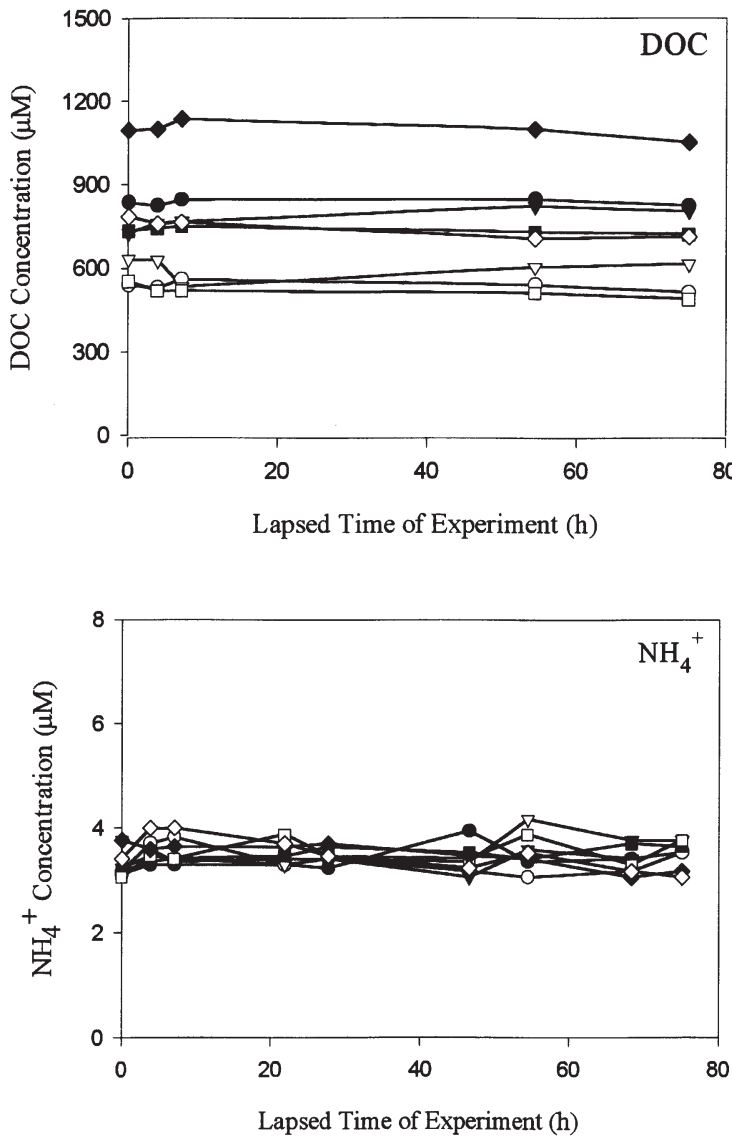

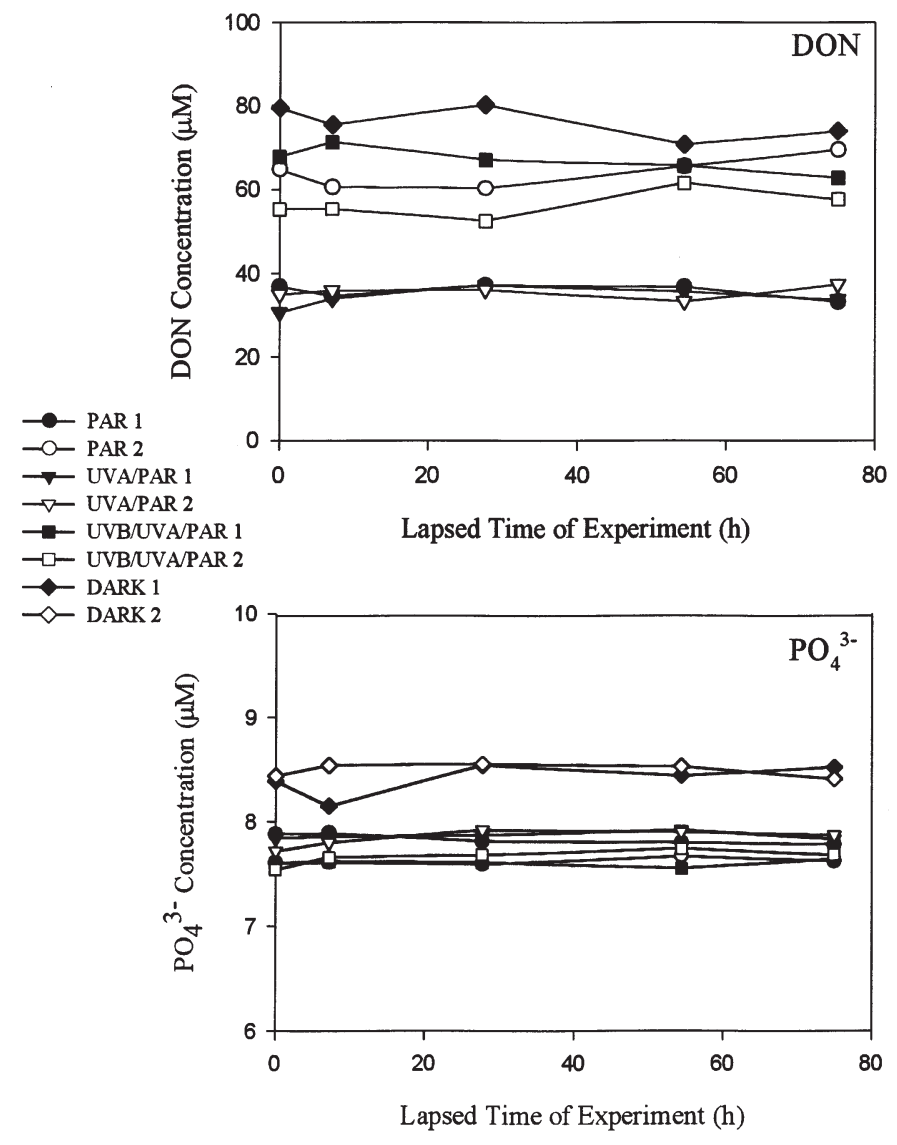

Fig. 2. DOC, DON, $\mathrm{NH}_{4}{ }^{+}$, and $\mathrm{PO}_{4}{ }^{3-}$ concentrations in swine pasture runoff from the photochemical degradation experiment. Samples were exposed to $35 \mathrm{~h}$ of sunlight over the course of $75 \mathrm{~h}$. Similar patterns for DOC, DON, $\mathrm{NH}_{4}{ }^{+}$, and $\mathrm{PO}_{4}{ }^{3-}$ concentrations were seen for the equine pasture and forest runoff

tions during these experiments is similar to the analytical variability associated with the DOC (5\%) and DON (10\%) methods. The $\mathrm{NH}_{4}{ }^{+}$and $\mathrm{PO}_{4}{ }^{3-}$ concentrations in either the agriculture or forest runoff did not significantly change $(p>0.05)$ during the experiments in 44 out of 48 time-series measurements (Fig. 2). DOC, DON, $\mathrm{NH}_{4}{ }^{+}$, and $\mathrm{PO}_{4}{ }^{3-}$ concentrations from the irradiated swine pasture runoff are presented as examples of the patterns observed in the photochemical degradation experiments for all sources (Fig. 2).

In contrast, a small, but significant increase in the $\mathrm{NO}_{3}{ }^{-} / \mathrm{NO}_{2}{ }^{-}$concentration (0.37 to $0.76 \mu \mathrm{M} \mathrm{NO}_{3}{ }^{-} / \mathrm{NO}_{2}{ }^{-}$) was detected for all light treatments in the irradiated forest runoff (power-transformed, $p=0.004$ ) (Fig. 3). No difference was found between light treatments, suggesting that UV did not affect the release of $\mathrm{NO}_{3}{ }^{-} / \mathrm{NO}_{2}{ }^{-}$from the $\mathrm{DON}$. The rate of $\mathrm{NO}_{3}{ }^{-} / \mathrm{NO}_{2}{ }^{-}$ production per sunlight hour ranged from 0.016 to $0.021 \mu \mathrm{M} \mathrm{NO}_{3}{ }^{-} / \mathrm{NO}_{2}{ }^{-} \mathrm{h}^{-1}$. The amount of $\mathrm{NO}_{3}{ }^{-} / \mathrm{NO}_{2}{ }^{-}$ released over the experiment represents 4 to $9 \%$ of the original DON concentration in the forest runoff. This percent change in the DON concentration was not

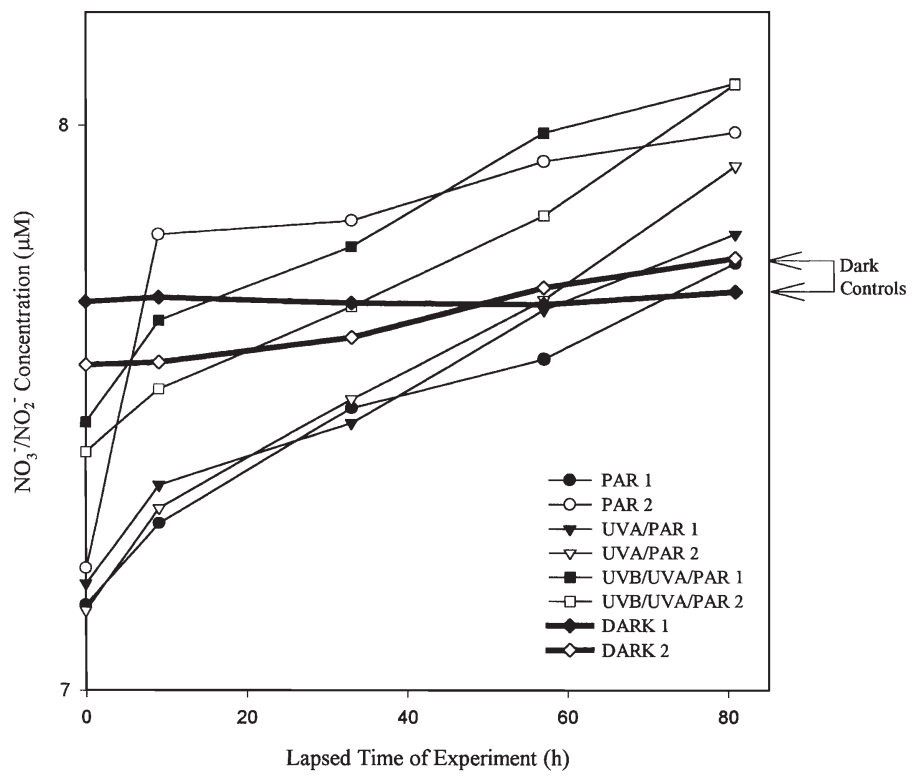

Fig. 3. Photochemical production of $\mathrm{NO}_{3}{ }^{-} / \mathrm{NO}_{2}{ }^{-}$from forest runoff. Samples were exposed to $38 \mathrm{~h}$ of sunlight over the course of $75 \mathrm{~h}$ 
detected, because it was within the range of analytical variability associated with the DON analysis $(10 \%)$. In the irradiated swine and equine pasture runoff, little or no photochemical release of $\mathrm{NO}_{3}{ }^{-} / \mathrm{NO}_{2}{ }^{-}$occurred.

\section{Microbial degradation of non-irradiated DOM}

The microbial community readily utilized the DOM, both the $\mathrm{C}$ and $\mathrm{N}$ components, from the agriculture and forest runoff (Fig. 4). The bacteria significantly decreased the DOC concentration $(p<0.05)$ in the agriculture and forest runoff; the absolute amount of DOC used by the bacteria ranged from 20 to $70 \mu \mathrm{M}$ DOC (Table 2). Similar absolute amounts of DOC were consumed in the swine and equine pasture runoff; this amount was at least 2 times greater than the amount used in the forest runoff (Table 2). A similar percent of DOC was consumed in the agriculture and forest runoff; it ranged from 6 to $14 \%$ (Table 2). Runoff from the animal pastures and forest supported statistically different amounts of bacterial production per initial $\mu \mathrm{M}$ DOC available $(\mathrm{p}=0.001$; Table 3$)$. Runoff from the equine pasture supported the highest amount of bacterial production per initial $\mu \mathrm{M}$ DOC available, followed by the forest and swine pasture, respectively (Table 3).

In most cases, the microbial community significantly decreased the DON concentration in the agriculture and forest runoff $(\mathrm{p}<0.05)$. The absolute amount of DON removed by the bacteria ranged from 2 to $17 \mu \mathrm{M}$ (Table 2). The percent of DON consumed from the different runoff sources was similar, ranging from 21 to $25 \%$ (Table 2 ).

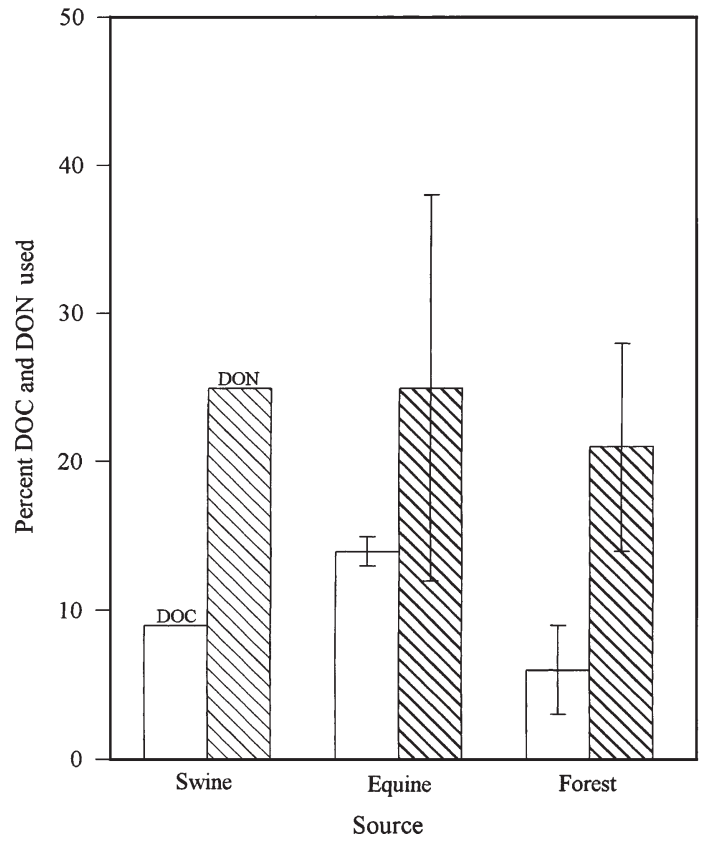

Fig. 4. Microbial degradation of non-irradiated DOC and DON. Degradation is shown as percent of original DOC and DON concentration utilized after $10 \mathrm{~d}$. Data are averages $( \pm \mathrm{SD})$ for duplicate treatment flasks

Small decreases in the $\mathrm{NH}_{4}{ }^{+}$and $\mathrm{PO}_{4}{ }^{3-}$ concentration were measured over the course of the experiment for the swine pasture, equine pasture, and forest runoff (Table 4). The $\mathrm{NO}_{3}{ }^{-} / \mathrm{NO}_{2}{ }^{-}$increased in the equine pasture runoff and decreased slightly in the swine pasture and forest runoff (Table 4).

Table 2. Microbial utilization $(\mu \mathrm{M})$ of DOC and DON in non-irradiated and irradiated DOM experiments. Data are averages $( \pm \mathrm{SD})$ for duplicate treatment flasks. All experiments ran for $10 \mathrm{~d}$

\begin{tabular}{|c|c|c|c|c|c|c|c|c|c|}
\hline \multirow{2}{*}{ DOM source } & \multirow{2}{*}{$\begin{array}{l}\text { Light } \\
\text { treatment }\end{array}$} & \multicolumn{3}{|c|}{$-\mathrm{DOC}$} & \multicolumn{3}{|c|}{$-\mathrm{DON}$} & \multirow{2}{*}{$\begin{array}{c}\text { Initial } \\
\mathrm{C}: \mathrm{N}\end{array}$} & \multirow{2}{*}{$\begin{array}{c}\text { Final } \\
\mathrm{C}: \mathrm{N}\end{array}$} \\
\hline & & $\begin{array}{l}\text { Initial } \\
\text { conc. }\end{array}$ & $\begin{array}{l}\text { Amount } \\
\text { used }\end{array}$ & $\%$ used & $\begin{array}{l}\text { Initial } \\
\text { conc. }\end{array}$ & $\begin{array}{c}\text { Amount } \\
\text { used }\end{array}$ & $\%$ used & & \\
\hline \multicolumn{10}{|c|}{ Non-irradiated DOM } \\
\hline Swine pasture & DARK & $642( \pm 28)$ & 61 & 9 & $61( \pm 12)$ & 17 & 25 & $11( \pm 2)$ & 12 \\
\hline Equine pasture & DARK & $487( \pm 2)$ & $70( \pm 6)$ & $14( \pm 1)$ & $47( \pm 1)$ & $11.5( \pm 6)$ & $25( \pm 13)$ & $10( \pm 0)$ & $19( \pm 1)$ \\
\hline Forest & DARK & $346( \pm 17)$ & $20( \pm 11)$ & $6( \pm 3)$ & $15( \pm 3)$ & $2( \pm 2)$ & $21( \pm 7)$ & $24( \pm 6)$ & $28( \pm 4)$ \\
\hline \multicolumn{10}{|l|}{ Irradiated DOM } \\
\hline \multirow[t]{4}{*}{ Equine pasture } & PAR & $437( \pm 23)$ & $24( \pm 8)$ & $5( \pm 2)$ & $50( \pm 9)$ & 4 & 6 & $9( \pm 2)$ & 8 \\
\hline & UVA/PAR & $635( \pm 27)$ & $100( \pm 36)$ & $16( \pm 5)$ & $54( \pm 14)$ & $22( \pm 8)$ & $44( \pm 27)$ & $12( \pm 4)$ & $22( \pm 15)$ \\
\hline & UVB/UVA/PAR & $465( \pm 23)$ & $80( \pm 29)$ & $17( \pm 5)$ & $49( \pm 2)$ & $5( \pm 5)$ & $11( \pm 10)$ & $10( \pm 0)$ & $9( \pm 1)$ \\
\hline & DARK & $553( \pm 3)$ & $89( \pm 2)$ & $16( \pm 0)$ & $54( \pm 8)$ & $13( \pm 5)$ & $25( \pm 14)$ & $10( \pm 2)$ & $12( \pm 4)$ \\
\hline \multirow[t]{4}{*}{ Forest } & PAR & $293( \pm 3)$ & $14( \pm 3)$ & $5( \pm 1)$ & $7( \pm 1)$ & 0.9 & 12 & $45( \pm 10)$ & 42 \\
\hline & UVA/PAR & $294( \pm 5)$ & $18( \pm 3)$ & $6( \pm 1)$ & $6( \pm 2)$ & $2.4( \pm 0.8)$ & $48( \pm 33)$ & $55( \pm 20)$ & $144( \pm 120)$ \\
\hline & UVB/UVA/PAR & $292( \pm 1)$ & $27( \pm 4)$ & $9( \pm 1)$ & $7( \pm 0)$ & $1.3( \pm 0.1)$ & $17( \pm 1)$ & $41( \pm 1)$ & $45( \pm 1)$ \\
\hline & DARK & $404( \pm 3)$ & $24( \pm 3)$ & $6( \pm 1)$ & $14( \pm 0)$ & $1.3( \pm 1.4)$ & $10( \pm 10)$ & $29( \pm 1)$ & $31( \pm 2)$ \\
\hline
\end{tabular}


Table 3. Average $( \pm \mathrm{SD})$ integrated bacterial production $(\mu \mathrm{M}$ bacterial $C \mu M^{-1}$ DOC) in non-irradiated and irradiated DOM experiments. Bacterial production measurements were normalized to initial concentrations of DOC present in the nonirradiated and irradiated DOM experiments

\begin{tabular}{|llc|}
\hline DOM source & Light treatment & $\begin{array}{c}\text { Integrated bacterial } \\
\text { production }\end{array}$ \\
\hline Non-irradiated DOM & \\
Swine pasture & DARK & $0.09( \pm 0.003)$ \\
Equine pasture & DARK & $0.12( \pm 0.002)$ \\
Forest & DARK & $0.10( \pm 0.001)$ \\
Irradiated DOM & & \\
Equine pasture & PAR & $0.09( \pm 0.01)$ \\
& UVA/PAR & $0.10( \pm 0.01)$ \\
& UVB/UVA/PAR & $0.15( \pm 0.06)$ \\
& DARK & $0.17( \pm 0.02)$ \\
Forest & PAR & $0.10( \pm 0.02)$ \\
& UVA/PAR & $0.13( \pm 0.01)$ \\
& UVB/UVA/PAR & $0.16( \pm 0.02)$ \\
& DARK & $0.10( \pm 0.002)$ \\
\hline
\end{tabular}

\section{Microbial degradation of irradiated DOM}

Irradiated DOC and DON from the equine pasture and forest runoff were readily used by the microbes (Table 2). In the equine pasture runoff, the absolute amount (rank-transformed; $\mathrm{p}=0.30$ ) and the percent of DOC consumed (rank-transformed; $\mathrm{p}=0.30$; Table 2) as well as the bacterial production (per initial $\mu \mathrm{M}$ DOC available; rank-transformed; $\mathrm{p}=0.12$; Table 3) were similar for both the light and dark control treatments. On average, the absolute amount of DOC consumed by the bacteria in the equine pasture runoff was $73( \pm 36) \mu \mathrm{M}$; this amount of C constituted $14 \%( \pm 6)$ of the initial amount present in the runoff (Table 2). In the forest runoff, the absolute amount $(p=0.05)$ and the percent of DOC consumed (rank-transformed; $\mathrm{p}=0.027$; Table 2) as well as the bacterial production (per initial $\mu \mathrm{M}$ DOC available; $\mathrm{p}=0.05$; Table 3 ) were significantly different only between the PAR and UVB/UVA/PAR treatments. The absolute amount of DOC consumed in the forest runoff ranged from 14 to $27 \mu \mathrm{M}$; this amount comprised between 5 to $9 \%$ of the DOC initially present in the runoff (Table 2).

In the irradiated equine pasture runoff, a similar absolute amount and percent of DON was consumed in both the light and dark control treatments (Table 2). A similar pattern was observed for the irradiated forest runoff (Table 2). The variability in the amount and percent of DON consumed in both DOM sources is similar to the variability observed in the non-irradiated DOM experiment (Table 2).

In both the equine pasture and forest runoff, there were generally small decreases in the $\mathrm{NH}_{4}{ }^{+}$and $\mathrm{PO}_{4}{ }^{3-}$ concentration and small increases in the $\mathrm{NO}_{3}{ }^{-} / \mathrm{NO}_{2}{ }^{-}$ concentration (Table 4). The $\mathrm{NO}_{3}{ }^{-} / \mathrm{NO}_{2}{ }^{-}$concentration increase in the light treatments in the forest runoff was negligible; the observed change in concentration was below the analytical detection range of the $\mathrm{NO}_{3}{ }^{-} / \mathrm{NO}_{2}{ }^{-}$ method. In contrast, similar amounts of $\mathrm{NO}_{3}{ }^{-} / \mathrm{NO}_{2}{ }^{-}$ were consumed in the irradiated forest runoff dark control and its counter part in the non-irradiated DOM experiment (Table 4).

\section{DISCUSSION}

\section{Role of photochemical degradation}

Studies examining photochemical degradation of DOM have primarily concentrated on DOC. Photochemical removal of DOC and production of DIC have

Table 4. Net decreases (-) and increases $(\mu \mathrm{M})$ in dissolved inorganic nitrogen and dissolved inorganic phosphate in non-irradiated and irradiated DOM experiments. Data are averages $( \pm \mathrm{SD})$ for duplicate flasks

\begin{tabular}{|c|c|c|c|c|c|c|c|}
\hline DOM source & $\begin{array}{l}\text { Light } \\
\text { treatment }\end{array}$ & \multicolumn{2}{|c|}{$\mathrm{NH}_{4}^{+}$} & \multicolumn{2}{|c|}{$\mathrm{NO}_{3}^{-} / \mathrm{NO}_{2}^{-}$} & \multicolumn{2}{|c|}{$\begin{array}{c}\mathrm{PO}_{4}{ }^{3-} \\
\text { Initial conc. Net change }\end{array}$} \\
\hline \multicolumn{8}{|c|}{ Non-irradiated DOM } \\
\hline Swine pasture & DARK & $3.5( \pm 0.1)$ & $-1.1( \pm 0.6)$ & $30.3( \pm 0.2)$ & $-0.2( \pm 0.3)$ & $8.3( \pm 0.0)$ & $-0.3( \pm 0.1)$ \\
\hline Equine pasture & DARK & $22.8( \pm 0.5)$ & $-1.6( \pm 0.7)$ & $107.9( \pm 0.5)$ & $2.4( \pm 2.2)$ & $1.6( \pm 0.0)$ & $-0.4( \pm 0.0)$ \\
\hline Forest & DARK & $1.0( \pm 0.3)$ & $-0.8( \pm 0.3)$ & $7.5( \pm 0.1)$ & $-0.4( \pm 0.1)$ & $0.9( \pm 0.0)$ & $-0.2( \pm 0.0)$ \\
\hline \multicolumn{8}{|c|}{ Irradiated DOM } \\
\hline \multirow[t]{4}{*}{ Equine pasture } & PAR & $25.6( \pm 0.0)$ & $-1.7( \pm 0.1)$ & $105.7( \pm 2.1)$ & $0.5( \pm 3.7)$ & $1.0( \pm 0.1)$ & $-0.2( \pm 0.0)$ \\
\hline & UVA/PAR & $28.5( \pm 0.0)$ & $-3.7( \pm 0.6)$ & $108.7( \pm 0.5)$ & $2.0( \pm 1.0)$ & $1.2( \pm 0.1)$ & $-0.3( \pm 0.0)$ \\
\hline & UVB/UVA/PAR & $25.3( \pm 0.3)$ & $-0.02( \pm 0.9)$ & $104.4( \pm 1.8)$ & $5.1( \pm 1.3)$ & $1.3( \pm 0.1)$ & $-0.4( \pm 0.2)$ \\
\hline & DARK & $25.8( \pm 1.2)$ & $-1.4( \pm 1.5)$ & $107.2( \pm 0.8)$ & $3.1( \pm 0.9)$ & $1.2( \pm 0.2)$ & $-0.2( \pm 0.2)$ \\
\hline \multirow[t]{4}{*}{ Forest } & PAR & $0.2( \pm 0.0)$ & $-0.04( \pm 0.1)$ & $8.0( \pm 0.1)$ & $0.04( \pm 0.0)$ & $0.7( \pm 0.0)$ & $-0.1( \pm 0.0)$ \\
\hline & UVA/PAR & $0.5( \pm 0.0)$ & $-0.2( \pm 0.1)$ & $7.9( \pm 0.0)$ & $0.2( \pm 0.1)$ & $0.7( \pm 0.0)$ & $-0.2( \pm 0.0)$ \\
\hline & UVB/UVA/PAR & $0.9( \pm 0.1)$ & $-0.6( \pm 0.1)$ & $8.1( \pm 0.1)$ & $0.02( \pm 0.1)$ & $0.7( \pm 0.0)$ & $-0.1( \pm 0.0)$ \\
\hline & DARK & $0.4( \pm 0.0)$ & $0.03( \pm 0.0)$ & $7.8( \pm 0.1)$ & $-0.5( \pm 0.2)$ & $0.9( \pm 0.0)$ & $-0.2( \pm 0.0)$ \\
\hline
\end{tabular}


Table 5. Photochemical removal of DOC from aquatic environments under natural sunlight

\begin{tabular}{|c|c|c|c|c|c|}
\hline Location & $\begin{array}{c}\text { Initial DOC } \\
(\mu \mathrm{M})\end{array}$ & $\begin{array}{l}\text { Light } \\
\text { treatment }\end{array}$ & $\begin{array}{l}\text { Sunlight } \\
\text { (h) }\end{array}$ & $\begin{array}{l}\% \text { DOC } \\
\text { removed }\end{array}$ & Source \\
\hline \multicolumn{6}{|l|}{ Rivers } \\
\hline Canadian headwater streams & $725-1500$ & UVB/UVA/PAR & 108 & $24-50$ & Molot \& Dillon (1997) \\
\hline Rio Negro, Amazon & $780-833$ & UVB/UVA/PAR & $4-27$ & $2-15$ & Amon \& Benner (1996b) \\
\hline Rio Solimóes, Amazon & 271 & UVB/UVA/PAR & 6 & 2 & Amon \& Benner (1996b) \\
\hline \multicolumn{6}{|l|}{ Lakes } \\
\hline Humic pond water, Norway & 1000 & UVB/UVA/PAR & 78 & $24-31$ & Hongve (1994) \\
\hline Clear and humic lakes, Sweden & $325-1620$ & UVB/UVA/PAR & 18 & $1.7-3.7$ & Granéli et al. (1996) \\
\hline Lake Lacawac, USA & 450 & UVB/UVA/PAR & 84 & 20 & Morris \& Hargreaves (1997) \\
\hline Lake Wagnewood, USA & 475 & UVB/UVA/PAR & 84 & 17 & Morris \& Hargreaves (1997) \\
\hline Lake Giles, USA & 133 & UVB/UVA/PAR & 84 & 0 & Morris \& Hargreaves (1997) \\
\hline \multicolumn{6}{|l|}{ Other } \\
\hline Nordic fulvic acid & 1833 & UVB/UVA/PAR & 78 & $22-32$ & Hongve (1994) \\
\hline Algal DOC & 17 & UVB/UVA/PAR & 8 & 0.2 & Tranvik \& Kokalj (1998) \\
\hline Swine pasture runoff & $552-734$ & UVB/UVA/PAR & 35 & 0 & This study \\
\hline Equine pasture runoff & $560-605$ & UVB/UVA/PAR & 21.5 & 0 & This study \\
\hline Forest runoff & $271-308$ & UVB/UVA/PAR & 38 & 0 & This study \\
\hline
\end{tabular}

been reported for environments spanning lakes to estuaries (Tables $5 \& 6$ ). Photochemical removal of DOC in these environments ranges from 0 to $50 \%$ under natural sunlight (Table 5) and up to $60 \%$ using artificial light sources (Table 6). The range in photochemical removal of DOC may result from the use of different DOC and light sources (spectral light distribution and intensity), as well as length of light exposure. Photochemical production of DIC has also been reported to occur with little or no change in the DOC concentration in high-carbon waters (Granéli et al. 1996, Jørgensen et al. 1998). This situation can occur when the amount of DOC photochemically degraded to DIC is much smaller than the amount of DOC originally present in the water. In our experiment, DOC may have been photochemically degraded to DIC; however, the amount of DOC degraded may have been too small for our DOC analysis to detect against the high DOC concentration background (271 to $734 \mu \mathrm{M}$ DOC).

Large DOC molecules can also be photochemically broken down into small organic compounds such as low molecular weight carbonyls, urea, amino acids, and carbohydrates (Kieber et al. 1990, Wetzel et al. 1995, Jørgensen et al. 1998). The DOC in our study may have been photochemically broken down into

Table 6. Photochemical removal of DOC from aquatic environments under artificial sunlight sources. nd: value not reported in this paper

\begin{tabular}{|c|c|c|c|c|c|}
\hline Location & $\begin{array}{l}\text { Initial DOC } \\
\qquad(\mu \mathrm{M})\end{array}$ & $\begin{array}{l}\text { Light } \\
\text { treatment }\end{array}$ & $\begin{array}{l}\text { Exposure } \\
\text { time (h) }\end{array}$ & $\begin{array}{l}\% \text { DOC } \\
\text { removed }\end{array}$ & Source \\
\hline \multicolumn{6}{|l|}{ Rivers } \\
\hline Suwanee River, USA & $4100-5150$ & UVB/UVA/PAR & 0.8 & $0.6-0.8$ & Miller \& Zepp (1995) \\
\hline \multicolumn{6}{|l|}{ Lakes } \\
\hline Rådasla, Sweden (surface) & 833 & $254 \mathrm{~nm}$ & 30 & $20-60$ & Allard et al. (1994) \\
\hline Lake Savojärvi, Finland & $1417-1767$ & $254 \mathrm{~nm}$ & $1-4$ & $0-22$ & Backlund (1992), Corin et al. (1996) \\
\hline Lake Savojärvi, Finland & 1717 & UVB/UVA/PAR & 168 & 60 & Kulovaara \& Backlund (1993) \\
\hline Lake Bjän, Sweden & 1325 & UVA & 89 & 4 & Dahlén et al. (1996) \\
\hline \multicolumn{6}{|l|}{ Coastal } \\
\hline Gulf of Mexico & 170 & UVB/UVA/PAR & $2.2-17.6$ & $0.7-4$ & Miller \& Zepp (1995) \\
\hline Saplo Island Marsh, USA & 500 & UVB/UVA/PAR & $2.2-89.9$ & $2-7$ & Miller \& Zepp (1995) \\
\hline \multicolumn{6}{|l|}{ Other } \\
\hline Aldrich soil humic acid & 667 & $254 \mathrm{~nm}$ & 60 & 57 & Allard et al. (1994) \\
\hline Aged algal DOC & nd & $300-400 \mathrm{~nm}$ & 15 & 0 & Thomas \& Lara (1995) \\
\hline Nordic fulvic acid & $5500-25000$ & $254 \mathrm{~nm}$ & 80 & 24 & Corin et al. (1996), Kulovaara et al. (1996) \\
\hline Nordic humic acid & 10417 & $254 \mathrm{~nm}$ & 80 & 35 & Corin et al. (1996), Kulovaara et al. (1996) \\
\hline
\end{tabular}


smaller organic compounds, but our measurements of DOC did not distinguish between small and large DOC molecules. However, the biological availability of the DOC in our equine pasture and forest runoff did not change after being exposed to light.

Less is known about what happens to the $\mathrm{N}$ component when DOM is exposed to light. Studies to date have reported the photochemical release of $\mathrm{NH}_{4}{ }^{+}$, $\mathrm{NO}_{2}{ }^{-}$, and small organic nitrogen compounds (Bushaw et al. 1996, Gardner et al. 1998, Jørgensen et al. 1998, Bushaw-Newton \& Moran 1999, Kieber et al. 1999). During our photochemical experiments, there was little or no change in either the DON or $\mathrm{NH}_{4}{ }^{+}$ concentration for any of the sources (Fig. 2). Other studies have also reported no significant changes in the DON or $\mathrm{NH}_{4}{ }^{+}$pool after sunlight exposure (Jørgensen et al. 1998, Bertilsson et al. 1999), but in some cases they have detected an increase in the urea and free amino acids concentration (Jørgensen et al. 1998). DON from our sources may have been broken down into smaller organic nitrogen compounds; however, its lability was not altered by light exposure (Table 2).

Photochemical reactions involving $\mathrm{NO}_{3}{ }^{-}$and $\mathrm{NO}_{2}{ }^{-}$ are well established. In these reactions, $\mathrm{NO}_{3}{ }^{-}$can be photochemically reduced to $\mathrm{NO}_{2}^{-}$and nitric oxide (NO) by ultra-violet radiation, resulting in either no net change or a decrease in the $\mathrm{NO}_{3}{ }^{-} / \mathrm{NO}_{2}{ }^{-}$pool (Zafiriou \& True 1979a,b). Increases in the combined $\mathrm{NO}_{3}{ }^{-} / \mathrm{NO}_{2}{ }^{-}$pool in the irradiated (all light treatments) forest runoff suggest that this process was not responsible for the observed pattern. Recent work has demonstrated that $\mathrm{NO}_{2}{ }^{-}$may be photochemically released from the nitroalkenes in the humic substances through oxidation by singlet oxygen under natural sunlight (Kieber et al. 1999). This process may provide a mechanism for the increased concentration of $\mathrm{NO}_{3}{ }^{-} / \mathrm{NO}_{2}{ }^{-}$seen in the forest runoff experiment (Fig. 3). The rate of $\mathrm{NO}_{3}{ }^{-} / \mathrm{NO}_{2}{ }^{-}$increase in our photochemical experiment ranged from 0.016 to $0.021 \mu \mathrm{M}$ $\mathrm{NO}_{3}^{-} / \mathrm{NO}_{2}^{-} \mathrm{h}^{-1}$, which was on average 4 to 5 times higher than the reported rate for nitrite production from humic substances $\left(0.0014\right.$ to $0.0067 \mu \mathrm{M} \mathrm{NO}_{2}{ }^{-} \mathrm{h}^{-1}$ : Kieber et al. 1999). The difference in $\mathrm{NO}_{3}{ }^{-} / \mathrm{NO}_{2}{ }^{-}$production rates from these 2 studies may result from the use of different organic matter sources, light distributions, and light intensities.

Phosphate can also be photochemically released from DOM. UV radiation reduces iron complexes that bind $\mathrm{PO}_{4}{ }^{3-}$ to humic substances, releasing $\mathrm{PO}_{4}{ }^{3-}$ into the surrounding environment (Francko \& Heath 1982). In our experiment, there was no measurable change in the $\mathrm{PO}_{4}{ }^{3-}$ concentration, suggesting that any $\mathrm{PO}_{4}{ }^{3-}$ bound to humic substances in our water was not photochemically released (Fig. 2).

\section{Role of microbial degradation of DOM}

The extent to which bacteria are degrading and incorporating allochthonous DOC into the biological cycle is becoming more readily recognized. DOC lability has been measured for a variety of DOM sources including point and non-point sources, rivers, lakes, estuaries, and the open ocean (Table 7). From 0 to $75 \%$ of the DOC in these environments has been shown to be labile to bacteria (Table 7); the percent of DOC consumed in our experiments ranged from 6 to $14 \%$ (Table 2).

From an ecosystem perspective, it is not only important to quantify how much DOC is removed by microbial processes, but also how much is incorporated into the microbial food web and higher trophic levels. One factor that has been demonstrated to affect the amount of DOC incorporated into bacterial biomass is DOM chemical composition (Sun et al. 1997, Hopkinson et al. 1998). In our study, the bacterial production supported by the DOC in the agriculture and forest runoff (Table 3) was not solely a function of the initial amount of DOC available or the absolute amount consumed (Table 2). These results suggest that there were qualitative differences between the DOC in the swine, equine, and forest runoff. Future research will help to more clearly define these patterns and provide data to develop a model to predict bioavailable DOC in a river based on its watershed's land-use distribution.

The biological availability of the nitrogen component in DOM has been measured in a few types of water: rain (Timperley et al. 1985, Peierls \& Paerl 1997, Seitzinger \& Sanders 1999), river (Carlsson et al. 1993, 1999, Seitzinger \& Sanders 1997), estuarine (Glibert et al. 1991, Bronk \& Glibert 1993), and wetland (Stepanauskas et al. 1999). The percent of DON degraded in these waters ranges from 0 to $75 \%$, which parallels or supersedes that of DOC (Table 8). In our study, a similar percent of DON was degraded for all DOM sources (Table 2). This result suggests that DON from all 3 sources was equally labile.

There appeared to be a trend of higher percent DON utilization by the bacteria relative to the DOC in the agriculture and forest runoff (Fig. 4). Several biological processes may result in higher utilization of DON relative to $\mathrm{DOC}_{i}$ these include enzymatic cleavage of $\mathrm{N}$-containing functional groups in the DOM molecule, selective decomposition of whole $\mathrm{N}$-rich molecules within the DOM mixture, and/or selective cleaving of the DOM molecule at the $\mathrm{N}$ component of the ring structure and preferential digestion of this component first. Our results suggest that $\mathrm{N}$ and $\mathrm{C}$ in DOM may be cycling at different rates in the aquatic environment. The preferential utilization of $\mathrm{N}$ relative to $\mathrm{C}$ may result in the export of $\mathrm{N}$-deplete allochthonous DOM from rivers to estuaries. 
Table 7. Microbial degradation of DOC in aquatic environments. nd: value not reported in this paper

\begin{tabular}{|c|c|c|c|c|}
\hline Location & $\begin{array}{l}\text { Initial DOC } \\
\qquad(\mu \mathrm{M})\end{array}$ & $\begin{array}{l}\text { Length of } \\
\text { experiment }(d)\end{array}$ & $\begin{array}{l}\% \text { DOC } \\
\text { utilized }\end{array}$ & Source \\
\hline \multicolumn{5}{|l|}{ Point and non-point sources } \\
\hline Brussels' main sewage collector, Belgium & 1050 & 15 & 43 & Servais et al. (1987) \\
\hline Windermere Basin (Lake Ontario), Canada & 1683 & 12 & 75 & Markosova (1991) \\
\hline STELCO Plant (Lake Ontario), Canada & 1392 & 12 & 57 & Markosova (1991) \\
\hline \multicolumn{5}{|l|}{ Rivers } \\
\hline Tamagawa River, Japan & 750 & 30 & 67 & Ogura (1975) \\
\hline Vistula River, Poland & $600-783$ & 90 & $23-36$ & Pempkowiak (1985) \\
\hline Forest River, Belgium & 150 & 15 & 11 & Servais et al. (1987) \\
\hline Meuse River, Belgium & $291-412$ & $15-28$ & $19-34$ & Servais et al. $(1987,1989)$ \\
\hline Scheldt River, Belgium & $738-1108$ & $15-28$ & $17-59$ & Servais et al. $(1987,1989)$ \\
\hline Rupel River, Belgium & $625-942$ & 28 & $26-54$ & Servais et al. (1989) \\
\hline Coweeta Hydrological Laboratory, USA & 500 & 134 & 25.8 & Qualls \& Haines (1992) \\
\hline Seine River, France & nd & 30 & $50-61$ & Servais \& Garnier (1993) \\
\hline Savannah River, USA & $267-358$ & $35-58$ & $6.5-17.7$ & Moran et al. (1999) \\
\hline Ogeechee River, USA & 317 & 35 & 7 & Moran et al. (1999) \\
\hline Altamaha River, USA & $258-267$ & $35-58$ & $6-7.3$ & Moran et al. (1999) \\
\hline Satilla River, USA & $275-2117$ & $35-98$ & $1.7-8.8$ & Moran et al. (1999) \\
\hline St. Marys River, USA & 350 & 35 & 8.3 & Moran et al. (1999) \\
\hline \multicolumn{5}{|l|}{ Lakes } \\
\hline Danish lakes & $100-1250$ & $10-21$ & $8-53$ & $\begin{array}{l}\text { Søndergaard (1984), } \\
\text { Søndergaard \& Borch (1992) }\end{array}$ \\
\hline Bog lakes, Japan & 916 & 90 & $16-41$ & Satoh \& Abe (1987) \\
\hline Humic lakes, Sweden & $1558-2567$ & 7 & $7-11$ & Tranvik (1988) \\
\hline Clear water lakes, Sweden & $408-1400$ & 7 & $5.9-13.7$ & Tranvik (1988) \\
\hline Lake Ontario, Canada & 1000 & 12 & 66 & Markosova (1991) \\
\hline \multicolumn{5}{|l|}{ Estuarine/coastal } \\
\hline Woods Hole Harbor, USA & 350 & 30 & $48-50$ & Barber (1968) \\
\hline Sagami Bay, Japan & 167 & 40 & 55 & Ogura (1975) \\
\hline Tokyo Bay, Japan & $133-256$ & $40-41$ & $22-60$ & Ogura (1975) \\
\hline Baltic Sea, Poland & $417-475$ & 90 & $30-43$ & Pempkowiak (1985) \\
\hline Schelds Estuary, Belgium & 494 & 15 & 25 & Servais et al. (1987) \\
\hline Belgian coastal zone & 223 & 15 & 30 & Servais et al. (1987) \\
\hline Elorn Estuary, France & $62.5-333$ & 240 & $22-34$ & Aminot et al. (1990) \\
\hline Roskilde Fjord, Denmark & $567-683$ & 28 & 15 & Middelboe et al. (1992) \\
\hline North Zealand coast & $383-442$ & 28 & $11-18$ & Middelboe et al. (1992) \\
\hline Northern Bothnian Sea & 320 & 5 & 7 & Zweifel et al. (1993) \\
\hline \multicolumn{5}{|l|}{ Open ocean } \\
\hline North Atlantic $\left(36^{\circ} 54^{\prime} \mathrm{N}, 68^{\circ} 11^{\prime} \mathrm{W}\right)$ & 300 & 60 & 0 & Barber (1968) \\
\hline North Equatorial Pacific & 80 & 50 & 23 & Ogura (1972) \\
\hline
\end{tabular}

Table 8. Microbial degradation of DON in aquatic environments

\begin{tabular}{|lcccc|}
\hline Location & Initial DON $(\mu \mathrm{M})$ & Length of experiment $(\mathrm{d})$ & $\%$ DON utilized & Source \\
\hline Rivers & & & & \\
$\begin{array}{l}\text { Delaware River, USA } \\
\text { Hudson River, USA }\end{array}$ & $12.9-46.5$ & $8-15$ & $40-72$ & $\begin{array}{l}\text { Seitzinger \& Sanders (1997) } \\
\text { Rain }\end{array}$ \\
$\begin{array}{l}\text { Philadelphia, USA } \\
\text { Wetlands }\end{array}$ & 17.5 & 10 & 40 & Seitzinger \& Sanders (1997) \\
$\begin{array}{l}\text { Amboke, Sweden } \\
\text { Vomb, Sweden }\end{array}$ & $16-32$ & $8-9$ & $46-75$ & Seitzinger \& Sanders (1999) \\
Isgrannatorp, Sweden & $13-109$ & & & \\
\end{tabular}




\section{Effects of light exposure on DOM lability}

Light exposure did not consistently alter DOC lability in the equine pasture and forest runoff. Light exposure did not affect the biological availability of the DOC in the equine pasture runoff (Table 2). Research to date has shown that exposure of DOC to light has contrasting effects on its biological availability to bacteria (Benner \& Biddanda 1998, Obernosterer et al. 1999). Exposure of DOC to sunlight has been shown to enhance, inhibit, and not change the bacterial consumption of the DOC (Lindell et al. 1995, Wetzel et al. 1995, Naganuma et al. 1996, Miller \& Moran 1997, Tranvik \& Kokalj 1998). These contrasting effects of sunlight exposure may result from differences in the DOC and bacterial community composition, as well as in the type of light (intensity and spectral distribution) used in these experiments.

In the forest runoff, the DOC exposed to PAR had a lower lability than the DOC exposed to UVB/UVA/PAR (Table 2). It is not clear why the DOC exposed to PAR had a lower biological availability compared to the UVB/UVA/PAR treatment, but not the other light treatments and the dark control. Radical production (i.e. hydrogen peroxide) from DOM may have altered its structure and lability by forming side chains and ring products (Mill et al. 1980); however, the likelihood that this mechanism altered the DOC lability in the PAR treatment is small. Previous studies have found that UV wavelengths are primarily responsible for radical production (Mopper \& Zhou 1990, Scully et al. 1996). The fact that PAR was also present in the other light treatments where the DOC lability did not differ from the dark control suggests that PAR may have not directly affected the DOC lability (Table 2). The low DOC lability observed in the PAR treatment is also not likely to have been an artifact of not mixing the runoff after ultrafiltration, since the initial DOC concentration in the PAR and UVB/UVA/PAR treatments were similar, suggesting that they were collected at comparable times during ultrafiltration.

The biological availability of DON in the equine pasture and forest runoff also was not affected by light (Table 2). The amount and the percent of DON consumed in the light and dark treatments were comparable for both sources (Table 2). Other studies have suggested that light exposure enhances DON lability; however, such studies did not directly measure the consumption of irradiated DON (Bushaw et al. 1996, Jørgensen et al. 1998, Bushaw-Newton \& Moran 1999). Their increased DON lability has been inferred from the fact that measured photochemical $\mathrm{N}$ products (amino acids and $\mathrm{NH}_{4}^{+}$) could not support the measured increase in bacterial production and abundance (Bushaw et al. 1996, Jørgensen et al. 1998, Bushaw-
Newton \& Moran 1999). The contrasting effects of sunlight on DON bioavailability are not surprising, given the contrasting effects seen with DOC.

\section{DOM in rivers}

Both photochemical and microbial processes have been shown to affect the amount and the rate at which DOC and DON are incorporated into the aquatic biological cycle (Wetzel et al. 1995, Bushaw et al. 1996, Miller \& Moran 1997, Jørgensen et al. 1998, BushawNewton \& Moran 1999). In our study, we found that microbial processes are more effective at degrading DOC and DON from agricultural and forest runoff than photochemical ones. Our DOC results from photochemical and microbial experiments are consistent with the previous findings in the literature (Miller \& Moran 1997). On average, photochemical (natural sunlight) and microbial degradation remove $11 \pm 10 \%$ (Table 5) and $27 \pm 17 \%$ (Table 7 ) of the DOC from different source waters, respectively. In our study, microbial processes removed 6 to $14 \%$ of the DOC from the agriculture and forest runoff (Table 2). Photochemical processes removed little to no DOC in either the agriculture or forest runoff (Fig. 2). As for DON, the microbes removed 21 to $25 \%$ of the DON from the runoff (Table 2); photochemical processes, at most, removed 4 to $9 \%$ of the DON through the release of $\mathrm{NO}_{3}{ }^{-} / \mathrm{NO}_{2}{ }^{-}$(Fig. 3). Exposing the DOC and DON in the equine pasture and forest runoff to light did not change their biological availability.

In the river environment, UV-driven photochemical processes are primarily limited to the near-surface waters, whereas microbial processes take place almost everywhere. Even under ideal conditions for photochemical processes like those found in riverine surface waters, photochemical processes had little to no effect on the concentration and bioavailability of the DOM from our sources. On the same time scale, microbial processes removed up to 14 and $25 \%$ of the DOC and DON from our source waters, respectively. In the context of the river, our results suggest that microbial processes may be more efficient at removing DOM than photochemical ones, and more important in affecting the quantity and quality of DOM exported from rivers to estuaries.

Acknowledgements. B. Hargreaves graciously provided us with both the data and model for quantifying light distributions. Insightful experimental design suggestions were provided by O. Schofield, R. Styles, R. Sanders, and L. Kerkhof. G. Lévai, R. Styles, R. DeKorsey, and P. Nawrot assisted in the laboratory and fieldwork. A. Laursen provided statistical advice. Location and laboratory space at Lacawac Sanctuary were arranged by J. Poppich. This research is the result of 
work funded by New Jersey Water Resources Research Institute and the NOAA Office of Sea Grant and Extramural programs, U.S. Department of Commerce, under Grant No. NA76-RG0091 (Publication No. NJSG-99-420). The US Government is authorized to produce and distribute reprints for governmental purposes notwithstanding any copyright notation that may appear hereon.

\section{LITERATURE CITED}

Allard B, Borén H, Pettersson C, Zhang G (1994) Degradation of humic substances by UV irradiation. Environ Int 20: 97-101

Aminot A, El-Sayed MA, Kerouel R (1990) Fate of natural and anthropogenic dissolved organic carbon in the macrotidal Elorn Estuary (France). Mar Chem 29:255-275

Amon R, Benner R (1996a) Bacterial utilization of different size classes of dissolved organic matter. Limnol Oceanogr 41:41-51

Amon R, Benner R (1996b) Photochemical and microbial consumption of dissolved organic carbon and dissolved oxygen in the Amazon River system. Geochim Cosmochim Acta 60:1783-1792

Anita NJ, Harrison PJ, Oliveira L (1991) The role of dissolved organic nitrogen in phytoplankton nutrition, cell biology and ecology. Phycologia 30:1-89

Backlund P (1992) Degradation of aquatic humic material by ultraviolet light. Chemosphere 25:1869-1878

Barber RT (1968) Dissolved organic carbon from deep waters resists microbial oxidation. Nature 220:274-275

Benner R, Biddanda B (1998) Photochemical transformations of surface and deep marine dissolved organic matter: effects on bacterial growth. Limnol Oceanogr 43:1373-1378

Bertilsson S, Stepanauskas R, Cuadros-Hansson R, Granéli W, Wikner J, Tranvik L (1999) Photochemically induced changes in bioavailable carbon and nitrogen in a boreal watershed. Aquat Microb Ecol 19:47-56

Bronk DA, Glibert PM (1993) Application of a ${ }^{15} \mathrm{~N}$ tracer method to the study of dissolved organic nitrogen uptake during spring and summer in Chesapeake Bay. Mar Biol 115:501-508

Bushaw KL, Zepp RG, Tarr MA, Schulz-Jander D, Bourbonniere RA, Hodson RE, Miller WL, Bronk DA, Moran MA (1996) Photochemical release of biologically available nitrogen from aquatic dissolved organic matter. Nature 381:404-407

Bushaw-Newton KL, Moran MA (1999) Photochemical formation of biologically available nitrogen from dissolved humic substances in coastal marine systems. Aquat Microb Ecol 18:285-292

Carlsson P, Segatto AZ, Granéli E (1993) Nitrogen bound to humic matter of terrestrial origin - a nitrogen pool for coastal phytoplankton? Mar Ecol Prog Ser 97:105-116

Carlsson P, Granéli E, Segatto AZ (1999) Cycling of biologically available nitrogen in riverine humic substances between marine bacteria, a heterotrophic nanoflagellate and a photosynthetic dinoflagellate. Aquat Microb Ecol 18:23-36

Corin N, Backlund P, Kulovaara M (1996) Degradation products formed during UV-irradiation of humic waters. Chemosphere 33:245-255

Dahlén J, Bertilsson S, Pettersson C (1996) Effects of UV-A irradiation on dissolved organic matter in humic surface waters. Environ Int 22:501-506

Francko DA, Heath RT (1982) UV-sensitive complex phosphorous: association with dissolved humic material and iron in a bog lake. Limnol Oceanogr 27:564-569

Gardner SW, Cavaletto JF, Bootsma HA, Lavrentyev PL, Troncone F (1998) Nitrogen cycling rates and light effects in tropical Lake Maracaibo, Venezuela. Limnol Oceanogr 43:1814-1825

Glibert PM, Garside C, Fuhrman JA, Roman MR (1991) Timedependent coupling of inorganic and organic nitrogen uptake and regeneration in the plume of the Chesapeake Bay estuary and its regulation by large heterotrophs. Limnol Oceanogr 36:895-909

Goldman JC, Caron DA, Dennett MR (1987) Regulation of gross growth efficiency and ammonium regeneration in bacteria by substrate C:N ratio. Limnol Oceanogr 32: 1239-1252

Granéli W, Lindell M, Tranvik L (1996) Photo-oxidative production of dissolved inorganic carbon in lakes of different humic content. Limnol Oceanogr 41:698-706

Heathwaite AL (1993) The impact of agriculture on dissolved nitrogen and phosphorus cycling in temperate ecosystems. Chem Ecol 8:217-231

Hongve D (1994) Sunlight degradation of aquatic humic substances. Acta Hydrochim Hydrobiol 22:117-120

Hopkinson C, Buffam I, Hobbie J, Vallino J, Perdue M, Eversmeyer B, Prahl F, Covert J, Hodson R, Moran MA, Smith E, Baross J, Crump B, Findlay S, Foreman K (1998) Terrestrial inputs of organic matter to coastal ecosystems: an intercomparison of chemical characteristics and bioavailability. Biogeochemistry 43:211-234

Jørgensen NOG, Tranvik L, Edling H, Granéli W, Lindell M (1998) Effects of sunlight on occurrence and bacterial turnover of specific carbon and nitrogen compounds in lake water. FEMS Microbiol Ecol 25:217-227

Kieber DJ, Mopper K (1987) Photochemical formation of glyoxylic and pyruvic acids in seawater. Mar Chem 21: 135-149

Kieber DJ, McDaniel J, Mopper K (1989) Photochemical source of biological substrates in sea water: implications for carbon cycling. Nature 341:637-639

Kieber RJ, Zhou X, Mopper K (1990) Formation of carbonyl compounds from UV-induced photodegradation of humic substances in natural waters: fate of riverine carbon in the sea. Limnol Oceanogr 35:1503-1515

Kieber RJ, Li A, Seaton PJ (1999) Production of nitrite from the photodegradation of dissolved organic matter in natural waters. Environ Sci Technol 33:993-998

Kirchman DL (1993) Leucine incorporation as a measure of biomass production by heterotrophic bacteria. In: Kemp PF, Sherr BF, Sherr EB, Cole JJ (eds) Handbook of methods in aquatic microbial ecology. Lewes, New York, p 509-512

Kulovaara M, Backlund P (1993) Effects of simulated sunlight on aquatic humic matter. Vatten 49:100-103

Kulovaara M, Corin N, Backlund P, Tervo J (1996) Impact of $\mathrm{UV}_{254}$-radiation on aquatic humic substances. Chemosphere 33:783-790

Lewis WM Jr, Saunders JR III (1989) Concentration and transport of dissolved and suspended substances in the Orinoco River. Biogeochemistry 7:203-240

Lindell MJ, Granéli W, Tranvik LJ (1995) Enhanced bacterial growth in response to photochemical transformation of dissolved organic matter. Limnol Oceanogr 40:195-199

López-Veneroni D, Cifuentes LA (1994) Transport of dissolved organic nitrogen in Mississippi River Plume and Texas-Louisiana continental shelf near-surface waters. Estuaries 17:796-808

Mantoura RFC, Woodward EMS (1983) Conservative behavior of riverine dissolved organic carbon in the Severn 
Estuary: chemical and geochemical implications. Geochim Cosmochim Acta 47:1293-1309

Markosova R (1991) Growth of bacterioplankton on dissolved organic carbon in Hamilton Harbour and Western Lake Ontario. Water Pollut Res J Can 26:173-185

Meyer JL, Edwards RT, Risley R (1987) Bacteria growth on dissolved organic carbon from a blackwater river. Microb Ecol 13:13-29

Middelboe M, Nielsen B, Søndergaard M (1992) Bacterial utilization of dissolved organic carbon (DOC) in coastal waters-determination of growth yield. Ergeb Limnol 37: $51-61$

Mill T, Hendry DG, Richardson H (1980) Free-radical oxidants in natural waters. Science 207:886-887

Miller WL, Moran MA (1997) Interaction of photochemical and microbial processes in the degradation of refractory dissolved organic matter from a coastal marine environment. Limnol Oceanogr 42:1317-1324

Miller WL, Zepp RG (1995) Photochemical production of dissolved inorganic carbon from terrestrial organic matter: significance to the oceanic organic carbon cycle. Geophys Res Lett 22:417-420

Molot LA, Dillon PJ (1997) Photolytic regulation of dissolved organic carbon in northern lakes. Global Biogeochem Cycles 11:357-365

Mopper K, Stahovec WL (1986) Sources and sinks of low molecular weight organic carbonyl compounds in seawater. Mar Chem 19:305-321

Mopper K, Zhou X (1990) Hydroxyl radical photoproduction in the sea and its potential impact on marine processes. Science 250:661-664

Moran MA, Sheldon WM, Sheldon JE (1999) Biodegradation of riverine dissolved organic carbon in five estuaries of the southeastern United States. Estuaries 22:55-64

Morris DP, Hargreaves BR (1997) The role of photochemical degradation of dissolved organic carbon in regulating the UV transparency of three lakes on the Pocono Plateau. Limnol Oceanogr 42:239-249

Naganuma T, Konishi S, Inoue T, Nakane T, Sukizaki S (1996) Photodegradation or photoalteration? Microbial assay of the effect of UV-B on dissolved organic matter. Mar Ecol Prog Ser 135:309-310

Obernosterer I, Reitner B, Herndl GJ (1999) Contrasting effects of solar radiation on dissolved organic matter and its bioavailability to marine bacterioplankton. Limnol Oceanogr 44:1645-1654

Ogura N (1972) Rate and extent of decomposition of dissolved organic matter in surface seawater. Mar Biol 13:89-93

Ogura N (1975) Further studies on decomposition of dissolved organic matter in coastal seawater. Mar Biol 31:101-111

Palenik B, Morel FMM (1990) Amino acid utilization by marine phytoplankton: a novel mechanism. Limnol Oceanogr 35: 260-269

Pantoja S, Lee C (1994) Cell-surface oxidation of amino acids in seawater. Limnol Oceanogr 39:1718-1726

Peierls BL, Paerl HW (1997) Bioavailability of atmospheric organic nitrogen deposition to coastal phytoplankton. Limnol Oceanogr 42:1819-1823

Pempkowiak J (1985) The input of biochemically labile and resistant organic matter to the Baltic Sea from the Vistula River. Mitt Geol-Paläont Inst Univ Hamburg 85:345-350

Porter KG, Feig YS (1980) The use of DAPI for identifying and counting aquatic microflora. Limnol Oceanogr 25:943-948

Potvin C, Roff DA (1993) Distribution-free and robust statistical methods: viable alternatives to parametric statistics? Ecology 74:1617-1628

Qualls RG, Haines BL (1992) Biodegradability of dissolved organic matter in forest throughfall, soil solution, and stream water. Soil Sci Soc Am J 56:578-586

Richey JS, McDowell WH, Likens GE (1985) Nitrogen transformations in a small mountain stream. Hydrobiologia 124: 129-139

Satoh Y, Abe H (1987) Dissolved organic matter in colored water from mountain bog pools in Japan. II. Biological decomposability. Arch Hydrobiol 111:25-35

Scully NM, McQueen DJ, Lean DRS (1996) Hydrogen peroxide formation: the interaction of ultraviolet radiation and dissolved organic carbon in lake waters along a $43-75^{\circ} \mathrm{N}$ gradient. Limnol Oceanogr 41:540-548

Seitzinger SP, Sanders RW (1997) Contribution of dissolved organic nitrogen from rivers to estuarine eutrophication. Mar Ecol Prog Ser 159:1-12

Seitzinger SP, Sanders RW (1999) Atmospheric inputs of dissolved organic nitrogen stimulate estuarine bacteria and phytoplankton. Limnol Oceanogr 44:721-730

Servais P, Garnier J (1993) Contribution of heterotrophic bacterial production to the carbon budget in the River Seine (France). Microb Ecol 25:19-33

Servais P, Billen B, Hascoët MC (1987) Determination of the biodegradable fraction of dissolved organic matter in waters. Water Res 21:445-450

Servais P, Anzil A, Ventresque C (1989) Simple method for determination of biodegradable dissolved organic carbon in water. Appl Environ Microbiol 55:2732-2734

Sharp JH, Benner R, Bennett L, Carlson CA, Dow R, Fitzwater SE (1993) Re-evaluation of high temperature combustion and chemical oxidation measurements of dissolved organic carbon in seawater. Limnol Oceanogr 38:1774-1782

Sharpley AN, Smith SJ, Williams JR (1988) Nonpoint source pollution impacts of agricultural land use. Lakes Reserv Manag 4:21-49

Smith DC, Azam F (1992) A simple, economical method for measuring bacterial protein synthesis rates in seawater using ${ }^{3} \mathrm{H}$-leucine. Mar Microb Food Webs 6:107-114

Solórzano L (1969) Determination of ammonia in natural waters by the phenolhypochlorite method. Limnol Oceanogr 14: 799-801

Søndergaard M (1984) Dissolved organic carbon in Danish lakes: concentration, composition, and lability. Verh Int Verein Limnol 22:780-784

Søndergaard M, Borch NH (1992) Decomposition of dissolved organic carbon (DOC) in lakes. Ergeb Limnol 37:9-20

Søndergaard M, Middelboe M (1995) A cross-system analysis of labile dissolved organic carbon. Mar Ecol Prog Ser 118: 283-294

Stepanauskas R, Leonardson L, Tranvik LJ (1999) Bioavailability of wetland-derived DON to freshwater and marine bacterioplankton. Limnol Oceanogr 44:1477-1485

Sun L, Perdue EM, Meyer JL, Weis J (1997) Use of elemental composition to predict bioavailability of dissolved organic matter in a Georgia river. Limnol Oceanogr 42:714-721

Thomas DN, Lara RJ (1995) Photodegradation of algal derived dissolved organic carbon. Mar Ecol Prog Ser 116:309-310

Timperley MH, Vigor-Brown RJ, Kawashima M, Ishigami M (1985) Organic nitrogen compounds in atmospheric precipitation: their chemistry and availability to phytoplankton. Can J Fish Aquat Sci 42:1171-1177

Tranvik LJ (1988) Availability of dissolved organic carbon for planktonic bacteria in oligotrophic lakes of differing humic content. Microb Ecol 16:311-322

Tranvik L, Kokalj S (1998) Decreased biodegradability of algal DOC due to interactive effects on UV radiation and humic matter. Aquat Microb Ecol 14:301-307

Wetzel RG, Hatcher PG, Bianchi TS (1995) Natural photolysis 
by ultraviolet irradiance of recalcitrant dissolved organic matter to simple substrates for rapid bacterial metabolism. Limnol Oceanogr 40:1369-1380

Zafiriou OC, True MB (1979a) Nitrite photolysis in seawater by sunlight. Mar Chem 8:9-32

Editorial responsibility: Fereidoun Rassoulzadegan, Villefranche-sur-Mer, France
Zafiriou OC, True MB (1979b) Nitrate photolysis in seawater by sunlight. Mar Chem 8:33-42

Zweifel UL, Norrman B, Hagström A (1993) Consumption of dissolved organic carbon by marine bacteria and demand for inorganic nutrients. Mar Ecol Prog Ser 101:23-32

Submitted: April 14, 2000; Accepted: December 15, 2000

Proofs received from author(s): February 27, 2001 